\title{
CONSTRUCTION OF MASCULINITY THROUGH BODYBUILDING: A QUALITATIVE STUDY
}

\author{
Bingül SUBAŞI HARMANCI ${ }^{1}$, Zihniye OKRAY ${ }^{2}$
}

\begin{tabular}{l} 
Article Info \\
\hline Araştırma Makalesi \\
DOI: $10.35379 /$ cusosbil.773123 \\
\hline Article History: \\
Received 24.07.2020 \\
Revised 23.02.2021 \\
Accepted $\quad 11.03 .2021$ \\
\hline Keywords: \\
Masculinity, \\
Body-building, \\
Body image, \\
Focus Group, \\
Discourse.
\end{tabular}

VÜCUT GELIŞTİRME ARACILIĞI İLE ERKEKLİK İNŞASI: NITTEL BİR

\begin{tabular}{l} 
Makale Bilgisi \\
\hline Research Article \\
DOI: $10.35379 /$ cusosbil.773123 \\
\hline Makale Geçmişi: \\
Geliş $\quad 24.07 .2020$ \\
Düzeltme 23.02 .2021 \\
Kabul $\quad 11.03 .2021$ \\
\hline Anahtar Kelimeler: \\
Erkeklik, \\
Vücut Geliştirme, \\
Beden Algisl, \\
Odak Grup, \\
Söylem. \\
\hline
\end{tabular}
\begin{abstract}
CCALISSMA
ABSTRACT

The body is a factor that makes men feel masculine and the role of the body in the construction of masculinity is undeniable. Bodybuilding has many features that are associated with masculinity such as performance, strength, muscular appearance, endurance. The scope of this study is to determine how male bodybuilding athletes construct masculinity through the body they construct and whether choosing this sport branch is meaningful in terms of masculinity. The data of the study were collected with a social constructivist stance, through a focus group interview. Participants of the study were four elite male bodybuilding athletes. According to the findings of the study, the participants were united in a common discourse that they started bodybuilding in order to be more muscular and bulky and that the ideal male body is bulky and intimidating. In addition, bodybuilding is considered as an area where participants can build masculinity and consider the new bodies they have built as an element of respect, a symbol of power. Bodybuilding represents the strength, power, and competence characteristics associated with masculinity for the participants, and is considered as an area where men can build a muscular appearance, which is the ideal body shape. In other words, through bodybuilding they use their bodies to construct masculinity.

\section{$\ddot{\mathbf{O Z}}$}

Beden erkeksi hissetmeyi sağlayan ve erkeklik inşasında rolü olan bir etkendir. Vücut geliştirme performans, güç, kaslı görünüş, dayanıklılık gibi erkeklikle özdeşleşen birçok özelliğe sahiptir. Bu çalışmanın amacı erkek vücut geliştirme sporcularının inşa ettikleri beden aracılığı ile erkekliği nasıl yapılandırdıkları ve bu spor dalını seçmenin erkeksilik açısından anlamı olup olmadığını tespit etmektir. Çalışmanın verileri sosyal inşacı bir duruşla, odak grup görüşmesi yapılarak toplanmıştır. Çalışmanın katılımcılarını 4 elit erkek vücut geliştirme sporcusu oluşturmuştur. Çalışma bulgularına göre katılımcılar daha kaslı ve daha büyük olmak amacıyla vücut geliştirmeye başladığını ve ideal erkek bedeninin büyük, korkutucu olduğu ortak söyleminde birleşmiştir. Ayrıca vücut geliştirme katılımcılar için erkeklik inşa edebilecekleri bir alan olarak düşünülmekte ve inşa ettikleri yeni bedenleri bir saygı unsuru, güç sembolü olarak değerlendirmektedir. Vücut geliștirme katılımcılar için erkeklikle özdeșleșen güç, kuvvet, yetkinlik özelliklerini temsil etmekte, erkeklerin ideal beden şekli olan kaslı görünüm inşa edebilecekleri bir alan olarak düşünülmektedir. Bir başka anlatımla katılımcılar bu spor aracılığı ile erkeklik inşasında bedenlerini kullanmaktadırlar.
\end{abstract}

\footnotetext{
${ }^{1}$ Dr., Yakın Doğu Üniversitesi, Fen Edebiyat Fakültesi, Psikoloji Bölümü, ORCID: 0000-0003-3633-622X.

${ }^{2}$ Doç. Dr., Lefke Avrupa Üniversitesi, Fen Edebiyat Fakültesi, Psikoloji Bölümü, ORCID: 0000-0002-9117-4991.

Alıntımak için/Cite as: Subaşı Harmancı, B., Okray, Z. (2021), Construction of Masculinity through Bodybuilding: A Qualitative Study, Çukurova Üniversitesi Sosyal Bilimler Enstitüsü Dergisi, 30 (1), 83-91.
} 


\section{INTRODUCTION}

Interest in bodybuilding is increasing day by day. Individuals who are interested in this sport are thought to be interested in such a sport with the aim of creating a more muscular, larger and stronger physical structure as well as creating a more aesthetic body shape (Tazegül and Güven, 2015; Ray, Demirkol, Tamam, 2012; Blouin and Goldfield, 1995). Individuals' efforts are towards looking more beautiful and they want to have an aesthetic body shape. Many studies show that people who are interested in bodybuilding sports care for their appearance and strive to have a good physical appearance (Tazegül and Güven, 2015). The main goal in bodybuilding is to have a symmetrical physical appearance that exhibits muscle size (Ploeg et al. 2001).

Muscule Dysmorphia (MD), which is a sub-type of Body Dysmorphia (BD), is a misperception of the body image, which is characterized by the fact that the person has a normal or muscular appearance and the body size is small and lean (Foster, Shorter, Griffiths and Griffiths, 2015). In men, body image disorder is suggested to be due to two factors: a desire to increase muscle and reduce fat (Santarnecchi and Déttore, 2012; Cafri, et al. 2005). Bodybuilding is an ideal sport for these people. Because in body building, the goal is to create a more muscular, big and strong physical structure (Cafri, et al. 2005). In this aspect, bodybuilding has features that are identified with masculinity (Karaçam, 2015). Bodybuilders are interested with their physical appearance in a obsessive way, dealing with extreme physical appearance could increase narcissistic behavior (Miller and Mesagno, 2014, Back, Schmukle and Egloff, 2010; Vazire, Naum, Rentfrow, and Goslin, 2008; Buffardi and Campbell 2008).

Bodybuilding is one of the sports which is appearence oriented (Hallsworth, Wade and Tiggeman, 2005) and people try to shape their muscles and improve their muscle mass, (Stoviks, 2006). The body is actively used and exhibited in many sports branches. Among other sport branches, bodybuilding is a sport that the body is more exhibited (Aranyosi, 2018). Body is a factor that makes men feel masculine. In this aspect, the role of the body in the construction of masculinity cannot be denied. Bodybuilding has many features that are identified with masculinity such as performance, strength, muscular appearance, endurance (Gattario et al. 2015, Karaçam, 2015).

In other words, in bodybuilding it is especially focused on the muscular physical appearance (Hallsworth, Wade and Tiggeman, 2005). Atheletes, interested with this sport, demonstrate their muscles (Gattario et al.,2015, Ploeg, et al. 2001), to have more muscle and less fat mass or seeks to increase muscle mass (Griffiths et al., 2015, Cafri et al. 2005). Bodybuilding differs from other weight lifting disciplines due to its aesthetic nature. Bodybuilding is a sports activity suitable for weight training and special nutrition programs to have a muscular physical appearance (Aranyosi, 2018, Mosley, 2009). Although there are female bodybuilders in bodybuilding, it is primarily one of the sports that is dominated by men (Mosley, 2009).

The studies show that the aesthetic sensitivity is high in BD. Aesthetic sensitivity shows that the value given to beauty and harmony is high (Ray et al. 2012). Researches indicate that athletes interested in bodybuilding sports are more interested in physical appearance than athletes interested in other sports (Blouin and Goldfield, 1995; Pasman and Thompson, 1998). Bodybuilding is one of the sports that people try to look more aesthetic and beautiful. In a study conducted by Tazegül and Güven (2015) in order to compare the levels of narcissism of athletes and non-athletes in different sports, the narcissistic characteristics of those who are engaged in bodybuilding are higher than other groups.

As the popularity of bodybuilders increases, it is suggested that a increasing number of young men are not satisfied with their physical appearance. The nature of this dissatisfaction is to be more muscular and larger (Devrim, Bilgic, Hongu, 2018, Pope, et al. 2000).

The research has identified a convincing positive relationship between narcissism and bodybuilding (Brown, 2000, Caroll,1989). In a study conducted by Caroll (1989) with bodybuilders, the score obtained from the inventory of narcissism was found to be significantly higher than runners and psychology students. This result shows that those who are interested in bodybuilding have more narcissistic characteristics than those who are interested in other sports (Miller, Mesagno, 2014).

In the study conducted by Karaçam (2015), it was determined that males use nutritional supplements in order to have an ideal body and to obtain a muscular body image. In other words, these people use nutritional supplements in the bodily expression of the masculine features such as the muscular body and power. The ideal men body consists of biceps, V-shaped body type covering the chest and shoulders. Men's desire to gain weight is also related to having an ideal V-shaped body and having more muscles (Lefkowich et al 2017, Furnham, Badmin and Sneade, 2002). In Karaçam's study with men who do bodybuilding, it was determined that the ideal male body focuses on muscular arms, wide chest and shoulders 


\section{Çukurova Üniversitesi Sosyal Bilimler Enstitüsü Dergisi, Cilt 30, Sayı 1, 2021, Sayfa 83-91}

and muscle mass concentrating on the abdominal muscle. In same study, they stated that muscular body is a power symbol for men and it has a relationship with masculinity and body. In another study it is emphasized that men are associated with the relationship between the muscular body and the sense of power and confidence in the social environment (Lefkowich et al. 2017, Grogan and Richards, 2002). The objective of this study is to determine how distinguished male bodybuilders construct masculinity from their discourse and whether this sport has a meaning for masculinity.

\section{METHODS}

To gain a deeper understanding of the meaning they assign to bodybuilding for male bodybuilders, data were collected from qualitative research methods through focus group interviews. The focus group interview conducted with a social constructive stance and how their beliefs are conducted in a social context; and it is aimed to reveal the discussion. Interaction between participants in the focus group interview constitutes the data of the research (Arkonaç, 2017). The meaning attributed to bodybuilding for male bodybuilders in masculinity building is a focus group discussion with elite competitive bodybuilders who are believed to share certain traits and particular experiences in order to reach deeper and richer information about the place of bodybuilding for bodybuilding men.

Before the interview process, YDÜ/SB/2018/137 (Yakın Doğu Üniversitesi, Sosyal Bilimler) numbered ethics committee approved taken from the Near East University Institute of Social Sciences in 06/04/2018. During the interview process, audio recording was taken with the permission of participants. In the interview, the personal characteristics of the participants, reasons for starting bodybuilding, the meaning of bodybuilding, forms of before and after bodybuilding, their perceptions about ideal male body, the views on such areas have been reached with the semi-structured interview form. Then, voice record analysis was performed by using discourse analysis method.

\section{Participants}

The number of participants in the focus group interview can vary from 2 to 8 (Arkonaç, 2017; Çokluk, 2011; Kitzinger, 1995). The participants of this study consisted of 4 elite male bodybuilders. The reason for choosing elite bodybuilder men for the study is the consideration that the most accurate and deepest information on this subject will be gained from them. Participants were included in the study on a voluntary basis.

\section{FINDINGS}

Reasons of Bodybuilding

Within the scope of the focus group interview the interviewed participants, who were four elite athletes stated that the reasons for starting bodybuilding are being more muscular and bulkier. Before starting this sport, despite each of them was interested in different sports, they described their previous body as thin and weak. In other words, they expressed their dissatisfaction with their previously thin and weak bodies. In addition to the desire to be muscular, ' 2 of them have expressed that, they have begun to have an interest in this sport by stubbornness'. Although each athlete has different reasons for starting bodybuilding, their common discourse is the 'desire to have a more muscular and bulky body'. This common ground for four of them, the reasons for starting this sport, merge on their bodies in the construction of masculinity. By increasing the muscle mass in their bodies, they describe the masculinity in their bodies with the goal of becoming bulky and muscular.

\section{Views On The Ideal Male Body}

When the participants are asked about their views on the ideal male body, their common discourse is that being a big one is scary, and the greatness is the symbol of power. The forms of qualifying the ideal male body reveal how they identify the masculinity and the body.

Participant (P)3 'the ideal male body should be over 90 pounds and above. A man must have a weight in appearance, must have a specific body structure and width'.

P2 'Not just appearance matters. There are some things that this appearance brings to man. These are power, strength and respectability, and these are things that must a man has'.

P1 'a man must scare the outside world with his body. He must has a bulky body structure. He has to give his girlfriend confidence with his body as he walks with his girlfriend'. 
P4 'must be bulky' they have revealed themselves.

\section{Participants' Body Shape Before Starting Bodybuilding}

In focus group interview, questions are asked to participants about how they perceive and evaluate their body before they started to engage bodybuilding,

P2 'I had a very thin body and I don't want to go back to my old physical appearance'.

P3 'I had a very thin body construction'.

$\mathrm{P} 4$ 'I had a very thin body as well'.

P1 'I had a very thin body as well'. As it can be clearly seen, a common discourse about their bodies before starting this sport is that they define their bodies as thin.

\section{The Meaning Attiributed To Bodybuilding}

Bodybuilding is thought to be an area where participants can give their bodies the shape they want and can construct masculinity. Besides, it is seen as an art rather than a sport. Despite all of the participants have already had a history of sportsmanship with different sports, the reasons why none of them wanted to continue and the meaning they attach to bodybuilding was expressed as;

P3 he explained as, 'bodybuilding is an art'. When he is asked what he meant by art he replied by saying 'it is an art you can play with every part of the body, it has an aesthetic aspect, it is not sports for me. Bodybuilding has an aesthetic aspect, every part in the body must be equal and from this perspective it is very appropriate for $m e$ '.

P2, "it is a very suitable branch of sports for my personality." When I asked exactly what he meant by his personality, "I have a bit of a nervous personality, a heavy body, an aesthetic image is important to me. I take my temper off my weights, will it beat me? Or will I beat it? I can give my body the shape I want. I enlarge my body if I want, or I can make it smaller. What I'm trying to say is that I can play as I want with the anatomy God gave me."

P4 "I forget everything when I go into the gym and start workout. I forget even the worst things. It's incredibly good for me. I get angry, but I leave the gym feeling comforted. When people get angry, they relax by using power. It is a very comforting process. I played basketball, I did athletics, but this kind of sport is something different, you're on your own, it's just your sport."

P1 “When I enter the hall, if I'm nervous, I take all my nerves out on the weights. Both my nerves become discharged and my body is shaped, and I gain a symmetrical appearance. In fact, this sport is not only for discharging one's nerves, but it also has an aesthetic aspect that shapes my body for me."

\section{Meaning and Gain Of The Body They Possess}

Bodybuilders evaluate their body as an element of respect and a symbol of power due to the meaning they attach to their body which is developed by bodybuilding and a gain provided them by their body. They also state that they perceive themselves as more developed than other males due to their rebuilt bodies and an element which increases their self-esteem. When it is asked about their opinions on the meaning of their body shape for them and the gains it provides, they said:

P4, "I had a very serious car accident and I was paralyzed below the chest. I was told I wouldn't be able to walk again.

My doctor told me that my muscles served as an airbag, otherwise I would be dead. I stubbed and walked. I continued my bodybuilding and increased my muscle mass."

P3, 'I'm more self-confident when I go somewhere. The normal person enters a place where he / she goes, and sits in a corner. When we enter, it is not like this, everyone looks at us.' 
Çukurova Üniversitesi Sosyal Bilimler Enstitüsü Dergisi, Cilt 30, Sayı 1, 2021, Sayfa 83-91

$\mathrm{P} 2$, 'there are advantages of having such a body.' When it is asked what these advantages are, P2 said: 'you are popular everywhere, people are afraid of you because of your body structure, they respect you because they fear. In addition, we are more than other people with this body.

\section{Changes In Their Body Caused By Bodybuilding}

They interpret the changes that occur in the body they rebuild together with the body building as the symbol of masculinity, power, size and durability. Through this new body shape they obtain, they can establish a multidimensional relationship between masculinity and bodybuilding. When the participants are asked about changes in body size after starting bodybuilding they responded as:

P4, 'I was slim before. When I wore a $t$-shirt, the arms would stay plentiful, now it is not. I can fill the clothes now. My strength has changed, I feel stronger, more durable, aesthetically changed".

P1, continues, 'as you can see, I was so thin, and now I grew larger, I am more powerful and I feel bigger'.

P3 shares the discourses of his friends: "change in my strength and appearance. I also notice that when I go somewhere, I impress other people. They come to me and ask: how did you do this body, tell us about it so we can achieve it too. I like to hear these kind of compliments."

P2 'actually we were human beings, we have turned into animals.'

The Impact Of Bodybuilding Athletes In Their Surrounding At The Beginning of Bodybuilding

The participants displayed in common how they were affected by being bulky and how their bulkiness intimidated others based on their own practical experiences. They expressed how they were affected by other bodybuilders by choosing this type of sport at the beginning of their bodybuilding venture as follows:

P4: "I was impressed by the fact that one of my relatives, who was involved in bodybuilding and who participated in the bodybuilding competition, was huge. I also saw another relative who lived in the States and was a state champion when I was a kid for the first time. I've never forgotten when he lifted me up with one hand. When he lifted me I asked myself: what is it? What is it like? I couldn't believe how a person could be so powerful. Then I grew up and told my relative who lived in Cyprus that I wanted to get into this business."

In addition, it is a common discourse that P1, P2, P3 and P4 were impressed by their elder brothers.

P3, 'When I saw P3 working out, I used to say that we should not go to the side where he was working out as he was huge."

P4, "not only P2 does have huge body or bodybuilding life, but he also has life outside the gym and it affects me seriously. When asked about what he meant by his life outside the gym: When I needed help, P4 always created out of nothing and solved my problem."

P1 said: 'The only person I saw alive working out and enjoyed is my brother, P2."

\section{The Role Of Nutritional Support In Masculinity Construction}

Regarding the additional nutrients used in the construction of masculinity, the participants stated that they were disturbed by the reactions they received from their environment.

They indicated that the people around them believe that the body shape they currently have is created by the additional nutrients they used, and that they are not happy with people clearly stating their opinions in this manner as they worked hard to have this body shape. In this way, they emphasize that the additional nutritional supplement they take is actually necessary to increase muscle mass and is inevitable in the construction of a masculine body.

P3 'the people around us think we have this body because of the protein powders we drink. They say that we have been inflated with those protein powders. These are completely absurd and unnecessary approaches."

P1 'everyone thinks that when you do few exercises, you can have a body like that. But that's not the case, you have to work. You can't grow where you sit as they think. It is essential to workout to develop. These additional foods only accelerate the growth. We have to take these because we spend more time on training rather than eating and our body needs additional food.'. 


\section{Çukurova Üniversitesi Sosyal Bilimler Enstitüsü Dergisi, Cilt 30, Sayı 1, 2021, Sayfa 83-91}

P2 'they are completely nutritional supplements. People say:if you take protein, your kidneys get tired, it gets hurt. It's true, but if you know the dose you've taken and you throw it away with sport, it has no harm."

\section{RESULTS AND DISCUSSION}

Bodybuilding men want to grow and enlarge their muscles and have a larger, bigger body. Having a muscular and large appearance is interpreted as a symbol of aesthetics and power on the other hand. In other words, these individuals build masculinity through the body and emphasize the dynamics between the body and masculinity by addressing the definition of masculinity through their bodies. The findings of the study were collected under eight main headings.

In the focus group interviews, the ideal body descriptions of the bodybuilding elite athletes interviewed were developed around the muscles, especially the muscles of the arm, the large breasts and the shoulders, as well as the abdominal muscles. This finding is consistent with the literature. It has been suggested that, the reason for the fact that bodybuilding is a sport which is male dominated, is explained as an area for developed arm muscles and the chest, as well as where large shoulders can be shaped by tightening towards the waist. In addition, it is stated that this body shape is the body type which is associated with masculinity (Mellor et al., 2014, Mishkin et al.1986). The ideal men body consists of V-shaped body type covering biceps, the chest and shoulders. In a study by Karaçam (2015), it was determined that the ideal male body focuses on increasing muscle mass concentrating on muscular arms, large chest and shoulders and abdominal muscle. Particularly, bodybuilding men choose such a sport in order to have an ideal male body.

In addition, participants intend to increase the muscle mass of their bodies, to be bulkier, and define masculinity through their bodies by sharing the rhetoric that the larger you are, the more intimidating you become. Moreover, that bulkiness is the symbol of power. The ways of characterizing the ideal male body reveal how they identify the male and the body. The muscular body is also perceived as an ideal body shape for men.

In addition, the body in question represents the features of strength,power and competence. These are associated with the type of man (Mishkind, Rodin, Silberstein and Striegel-Moore, 1986).

Bodybuilding is a sport that people try to look more aesthetic and beautiful (Tazegül and Güven, 2015; Ray, Demirkol and Tamam, 2012; Blouin and Goldfield, 1995). Because of its aesthetic quality, it is a sport that is separated from other weight lifting disciplines (Moosley, 2009). In this study, bodybuilding is considered as an area where participants can build the shape they want, and build masculinity. Although all of the participants had already had a history in different sports, none of them wanted to continue those sports. The reason for not wanting is the fact that bodybuilding is an individual sport which has the aesthetic aspect that can give the body the shape they want which is a common discourse. It is the common discourse that success in team sports is interpreted as team success, but success in bodybuilding is interpreted as their personal success. Also unlike team sports, bodybuilding is interpreted as an area where it can show its individual abilities. Many studies reveal that athletes interested in bodybuilding are more involved with their physical appearance than athletes interested in different sports (Blouin and Goldfield, 1995; Pasman and Thompson, 1998). Bodybuilding is inherently competitive and differs from other branches of sports based on a common goal.

Bodybuilding has an individualized character (Stoviks, 2006). Bodybuilding is thought to be an area where participants can demonstrate their individual strength by giving their body the shape they desire.

The participants shared their dissatisfaction with their bodies before starting to develop and described their bodies as slim. Bodybuilding is thought to be an area that they can build a muscular image which is the ideal body shape of masculinity.

The body that budybuilding athletes create by doing building puts a significant importance to the meaning of body. To put in other words, meaning given to them as the gain is important. They stated that they perceived their bodies as a symbol of respect, a symbol of power, and also because they were rebuilt by their body, they perceived that they were superior than other men. This perception increased their self-confidence. According to the participants, the muscular body is a symbol of power, a self-confidence-enhancing factor, which puts them in an outstanding position compared to other men. In a study carried out by Karaçam (2015) with bodybuilding men, males have established a relationship between their bodies and masculinity, suggesting that being muscular is the symbol of man's power. In another study, it was determined that men establish relationship between the muscular body and the feeling of power and confidence in the social environment (Grogan and Richards, 2002).

The participants expressed that they were uncomfortable with the reactions they received from their environment in regard to additional nutrients used in the construction of masculinity. They stated that the people around them thought that the body shape they had at the moment was created by the additional foods they used, 


\section{Çukurova Üniversitesi Sosyal Bilimler Enstitüsü Dergisi, Cilt 30, Sayı 1, 2021, Sayfa 83-91}

and that they were not happy with these expressions as they were working hard to obtain the body shape they currently have. One of the purposes of using Anabolic (muscle development), Androgenic (masculinity) steroids is to gain an athletic image and increase performance (Bahrke, 2005). In the study conducted by Karaçam (2015), it was determined that males use additional nutritional support in order to have an ideal body and to obtain a muscular image. Expressly, these people use nutritional supplements in somatization of the masculinity, such as muscularity and strength. However, they stated that their new body shape was not created by food nutrients rather than it was created thanks to their hardwork and their own efforts, which is considered to be a narcissistic feature. It is known that the narcissistic characteristics of bodybuilders with anabolic androgenic steroid use are higher than those who do not use (Porcerelli and Sandler, 1995).

What the participants displayed in common is, how they were affected by being bulky and how their bulkiness intimidated others as well as their increased self-esteem in the places they enter based on their own practical experiences. Studies showed that men created a relationship between strength and confidence in the muscular body and social environments (Christensen and Jensen, 2014, Grogan and Richards 2002). In other words, bodybuilding individuals appear to be stronger in their environment through the new bodies they have built which increases their confidence. Their bodies allow them to become powerful, a concept that is associated with masculinity.

\section{REFERENCES}

Aranyosi, I. (2018). Body, Skill and Look: Is Bodybuilng a Sport? Phenom Cog Sci. 17, 401-410.

Arkonaç, SA (2017). Psikolojide Söz ve Anlam Analizi: Niteliksel Duruş. Hiperlink Yayınları.

Back, MD, Schmukle, SC, Egloff, B. (2010). Why are Narcissistis so Charming at First Sight? Decoding The Narcissism-Popularity Link at Zero Acquaintance. Journal of Personality and Soial Psychology. 98 (1), 132-145.

Bahrke, SM (2005). Psychological and Behavioral Effects of Anabolic-Androgenic Steroids. International Journal Of Sports And Exercise Psychology, 3(4), 428-445.

Blouin, GA, Goldfield, GS (1995). Body Image and Steroid Use In Male Bodybuilders. International Journal of Eating Disorders, 18(2), 159-165.

Buffardi, LE, Campbell, WK (2008). Narcissism and Social Networking Web Sites. Personality and Social Psychology Bulletin, 10, 1303-1314.

Brown, LB (2000). Powerful Physiques, Vulnerable Psyches: Narcissism, Body Image and Masculinity in Male Bodybuilders. The Sciences and Engineering, 61 (7-), 3833

Cafri, G., Thompson, K., Ricciardelli, L., McCabe, M., Smolak, L. and Yesalis, C. (2005). Pursuit $\quad$ Of The Muscular Ideal: Physical and Psychological Consequences and Putative Risk Factor. Clinical Psychology Review, 25, 215-239.

Carroll, L. (1989). A Comparative Study Of Narcissism, Gender, and Sex-Role Orientation Among Bodybuilders, Athletes, and Psychology Students. Psychological Reports, 64 (3), 999-1006.

Christensen, A., \& Jensen, SQ (2014). Combining hegemonic masculinity and intersectionality. Nordic Journal for Masculinity Studies, 9, 60-75.

Çokluk, Ö. (2011). Nitel Bir Görüşme Yöntemi: Odak Grup Görüşmesi. Kuramsal Eğitimbilim, 4 (1), 95-107.

Devrim, A., Bilgic, P. and Hongu, N. (2018). Is There Any Relationship Between Body Image Perception, Eating Disorders, and Muscle Dysmorphic Disorders in Male Bodybuilders? American Journal of Men's Health, 12(5), 1746-1758 
Çukurova Üniversitesi Sosyal Bilimler Enstitüsü Dergisi, Cilt 30, Sayı 1, 2021, Sayfa 83-91

Foster, CA, Shorter, WG, Griffiths, DG and Griffiths, DM (2015). Muscle Dysmorphia: Could it be Classified as an Addition to Body Image. Journal of Behavioral Addictions, 4(1), 1-5.

Furnham, A., Badmin, N. and Seneade, I. (2002). Body Image Dissatisfaction: Gender Differences in Eating Attitudes, Self Esteem and Reasons for Exercise. The Journal of Psychology, 136(6), 581-596.

Gattario, KH, Frisén, A., Fuller-Tyszkiewicz, M., Ricciardelli, LA., Diedrichs, PC., Yager, Z. and Smolak, L. (2015). How is Men's Conformity to Masculine Norms Related to Their Body Image? Masculinity and Muscularity Across Western Countries. Psychology of Men \& Masculinity, 16, 337-347.

Griffiths, S., Murray, S., and Touyz, S. (2015). Extending the masculinity hypothesis. An investigation of gender role conformity, body dissatisfaction, and disordered eating in young heterosexual men. Psychology of Men \& Masculinity, 16, 108-114.

Grogan, S. and Richards, H. (2002). Body Image: Focus Groups with Boys and Men. Men and Masculinities, 4(3), 219-232.

Hallsworth, L., Wade, T. and Tiggeman, M. (2005). Individual Differences in Male Body Image:

An Examination of Self Objectification in Recreational Bodybuilders. Br JHealth Psychol, 10(3),453-65.

Karaçam, MŞ (2015). Vücut Geliştirme Alanında Erkeklik Kimliğinin İnşasında Besin Desteğini Yeri [Yükssek Lisans Tezi, Hacettepe Üniversitesi].

Kitzinger, J. (1994). The Methodology of Focus Groups: The Importanceof Interaction Between Research Participants. Sociology of Health and Illness, 16(1) 103-121.

Lefkowich, M., Oliffe, LJ, Clarke, LH and Hannan-Leith, M. (2017). Male Body Practices: Pitches, Purchases, and Performativities. American Journal of Men's Health, 11(2) 454-463.

Mellor, D, Hucker, A., Waterhouse, M., Mamat, NH, Xu, X., Cochrane, J., McCabe, M. and Ricciardelli, L. (2014). A Cross-Cultural Study Investigating Body Features Associated With Male Adolescents' Body Dissatisfaction in Australia, China, and Malaysia. American Journal of Men's Health, 8(6) 521-531.

Miller, KJ and Mesagno, C. (2014). Personality traits and exercise dependence: Exploring the role of narcissism and perfectionism. International Journal of Sport and Exercise Psychology, 12 (4), 368-381.

Mishkind, ME, Rodin, J., Silberstein, LR and Striegel-Moore, RH (1986). The Embodiment of Masculinity: Cultural, Psychological, and Behavioral Dimensions. American Behavioural Scientist, 29, 545-562.

Mosley, FE (2009). Bigorexia: Bodybuilding and Muscle Dysmorphia. Eur Eat Disorders Rev. 17, $191-98$.

Pasman, L., Thompson, JK (1988). Body Image and Eating Disturbance in Obligatory Runners, Obligatory Weightlifters and Sedentary Individuals. lnt J Eat Disord, 7(6),759-769.

Ploeg, GE, Brooks, AG, Withers, RT, Dolman, J., Leaney, F. and Chatterton, BE (2001). Body Composition Changes in Female Bodybuilders During Preparation for Competition. Eur J Clin Nutr. 55, 268-77.

Pope, HG. Jr., Gruber, AJ, Mangweth, B., Bureau, B., deCol, C., Jouvent, R. and Hudson, JI (2000). Body Image Perception Among Men in Three Countries. American Journal of Psychiatry, 157, 1297-1301.

Porcerelli, HJ and Sandler, AB (1995). Narcissism and Empathy in Steroid Users. Am J Psychiatry, 152, 16721674. 
Çukurova Üniversitesi Sosyal Bilimler Enstitüsü Dergisi, Cilt 30, Say1 1, 2021, Sayfa 83-91

Ray, ÇP, Demirkol, EM and Tamam, L. (2012). Beden Dismorfik Bozukluğu. Psikiyatride Güncel Yaklaşımlar. 4(4),547-565.

Santarnecchi, E. And Déttore, D. (2012). Muscle Dysmorphia In Different Digrees of Bodybuilding Activities: Valifdation of the Italian Version of Muscle Dysmorphia Disorder Inventory and Bodybuilder Image Grid. Body Image, 9, 396-403.

Stoviks, R. (2006). The Emancipation of Bodybuilding. Sports in Society, 9(3), 463-479.

Tazegül, Ü. (2013). Farklı Branştaki Sporcuların Narsisizm Düzeyleri ile Sosyo-Demografik Özellikleri Arasındaki İlişkinin İncelenmesi. Spor ve Performans Araştırmaları Dergisi, 4(1), 23-32.

Tazegül, Ü. ve Güven, Ö. (2015). Vücut Geliştirme Sporcuları ile Farkli Spor Dallarındaki Elit Sporcuların Ve Spor Yapmayan Bireylerin Narsisizm Seviyelerinin Karşılaştırılması. Journal of Academic Social Science Studies, 33, 465-473.

Vazire, S., Naumann LP, Rentfrow, PJ and Gosling, SD (2008). Portrait of a Narcissist: Manifestations of Narcissism In Physical Appearance. Journal of Research in Personality, 42, 1439-1447.

Çalışmanın etik kurul onayı Yakın Doğu Üniversitesi, Sosyal Bilimler Enstitüsünün YDÜ/SB/2018/137 kararı ile 06/04/2018 tarihinde alınmıştır. 